Vol. 1 No. 1, Feb 2021, hlm. $79-88$

DOI: https://doi.org/10.33330/.v1i1.1048

Available online at https://jurnal.stmikroyal.ac.id/index.php/jutsi

\title{
PENERAPAN STRATEGI CUSTOMER RELATIONSHIP MANAGEMENT PADA PENJUALAN KERAJINAN TANGAN
}

\author{
Zulika Maduri $^{1,}$ Jeperson Hutahaean $^{2 *}$, Sri Rezki Maulina Azmi ${ }^{3}$ \\ ${ }^{1}$ Mahasiswa Prodi Sistem Informasi, STMIK Royal \\ ${ }^{2}$ Prodi Sistem Informasi, STMIK Royal \\ ${ }^{3}$ Prodi Manajemen Informatika, STMIK Royal \\ *email: jepersonhutahaean@royal.ac.id
}

\begin{abstract}
This research aims to manage sales data of various handicraft products online and improve customer service at Fahraz Glass Store using Customer Relationship Management (CRM) method. The research method used in this research is qualitative method. The application is built using php programming language and Mysql database. The implementation of Customer Relationship Management method at Fahraz Glass Store makes it easy for customers to get the latest product information and make product purchase transactions quickly. In addition, with the facilities of comments, customers can do product testimonials, submit questions, criticisms and suggestions and get answers directly from the admin so as to improve service to customers.
\end{abstract}

Keywords: Customer Relationship Management, Handicraft Products, Member

\begin{abstract}
Abstrak : Penelitian ini bertujuan untuk mengelola data penjualan berbagai macam produk kerajinan tangan secara online dan meningkatkan pelayanan terhadap pelanggan pada Toko Glass Fahraz menggunakan metode Customer Relationship Management (CRM). Metode penelitian yang digunakan dalam penelitian ini adalah metode kualitatif. Aplikasi dibangun menggunakan bahasa pemrograman PHP dan database Mysql. Hasil implementasi penerapan metode Customer Relationship Management pada Toko Glass Fahraz memberikan kemudahan bagi pelanggan untuk mendapatkan informasi produk terbaru dan melakukan transaksi pembelian produk secara cepat. Selain itu dengan adanya fasilitas komentar maka pelanggan dapat melakukan testimoni produk, menyampaikan pertanyaan, kritik mupun saran dan memperoleh jawaban langsung dari admin sehingga dapat meningkatkan pelayanan terhadap pelanggan.
\end{abstract}

Kata Kunci: Customer Relationship Management, Kerajinan Tangan, Pelanggan

\section{PENDAHULUAN}

Kehadiran internet mengubah cara-cara perusahaan dalam menghubungkan dirinya dengan pelanggan mereka. Pelanggan biasanya membuka website perusahaan untuk melihat informasi produk yang ditawarkan. Selanjutnya pelanggan akan melakukan transaksi pembelian produk secara online. Untuk itu, perusahaan harus lebih inovatif dan kreatif dalam menjalankan proses bisnisnya, serta perlu adanya suatu 
Vol. 1 No. 1, Feb 2021, hlm. $79-88$

DOI: https://doi.org/10.33330/.v1i1.1048

Available online at https://jurnal.stmikroyal.ac.id/index.php/jutsi

strategi khusus untuk mendapatkan pelanggan baru maupun mempertahankan pelanggan lama.

Penelitian ini dilakukan pada Toko Glass Fahraz yang berlokasi di daerah Tanjung Balai. Toko Glass Fahraz merupakan toko yang menjual berbagai macam produk kerajinan tangan yang terbuat dari kerang dan siput, yang tentu saja hal tersebut terkait dengan ciri khas kota Tanjungbalai yang terkenal sebagai kota kerang. Produk kerajinan tangan yang dijual pada Toko Glass Fahraz banyak disenangi oleh masyarakat sekitar Tanjung balai khususnya Pematang Pasir.

Namun, saat ini Toko Glass Fahraz belum memiliki strategi khusus dalam penjualan produk dan pelayanan terhadap pelanggan. Penjualan produk kerajinan tangan dilakukan dengan cara memajang produk pada toko. Pelanggan harus datang ke Toko untuk melakukan pembelian produk. Transaksi dilakukan dengan mencatat data pembelian produk pada nota pembelian, kemudian secara berkala nota tersebut akan direkap untuk pembuatan laporan. Selain itu, proses pemasaran produk hanya disampaikan dari mulut ke mulut, sehingga area pemasaran produk yang dijual terbatas.

Untuk itu perlu dilakukan perbaikan terhadap sistem yang sedang berjalan di Toko Glass Fahraz agar dapat memenuhi kebutuhan pelanggan dengan menerapkan metode Customer Relationship Management (CRM). CRM merupakan suatu strategi perusahaan yang digunakan untuk memanjakan pelanggan agar tidak berpaling kepada pesaing [1]. CRM merupakan sebuah filosofi bisnis yang menggambarkan suatu strategi penempatan client sebagai pusat proses, aktivitas dan budaya [2]. CRM merupakan usaha yang melibatkan semua sumber daya perusahaan dalam menjalin, mengelola, dan mempertahankan hubungan dengan pelanggan yang ada, serta mengetahui apa yang menjadi minat pelanggan [3]. CRM mampu menghasilkan suatu strategi yang lebih baik dengan cara mengimplementasikan suatu produk teknologi komunikasi informasi yang dapat membantu usaha ini menjadi lebih efektif dalam meningkatkan layanan marketing dan customer support [4].

\section{METODE}

Kerangka kerja penelitian digunakan dengan tujuan mempermudah dalam melaksnakan penelitian ini. Adapun kerangka kerja penelitian adalah : (1) Identifikasi Masalah, Menentukan judul dan melakukan identifikasi permasalahan yang ada., (2) Studi literatur, Untuk menyelesaikan permasalahan yang terjadi di Toko Glass Fahraz maka dilakukan pencarian literatur yang diperoleh dari berbagai sumber seperti buku dan jurnal yang berkaitan dengan penerapan metode CRM pada strategi pemasaran penjualan dan pelayanan terhadap pelanggan., (3) Pengumpulan Data, Pengumpulan data yang digunakan sebagai bahan pendukung dalam penelitian ini yaitu dengan cara melakukan observasi dan wawancara yang dilakukan di Toko Glass Fahraz sehingga memperoleh data dan informasi yang dibutuhkan., (4) Pendekatan Metode, Metode yang digunakan dalam penelitian ini adalah metode Customer Relationship Management., (5) Perancangan Sistem, Perancangan Sistem pemodelan data menggunakan flowmap, UML. Kemudian dilakukan perancangan database dan user interface., (6) Pengujian Sistem, Pengujian dilakukan untuk menilai apakah yang telah dirancang tersebut sesuai dengan apa yang diharapkan. Pengujian yang dilakukan 
Vol. 1 No. 1, Feb 2021, hlm. $79-88$

DOI: https://doi.org/10.33330/.v1i1.1048

Available online at https://jurnal.stmikroyal.ac.id/index.php/jutsi

terhadap sistem yaitu menggunakan metode Black Box., (7) Implementasi Sistem, Implementasi sistem dilakukan dengan penerjemahan hasil dari analisis dan perancangan kedalam bahasa pemrograman. Kemudian menerapkan sistem tersebut.

\section{HASIL DAN PEMBAHASAN}

Penerapan Metode Customer Relationship Management (CRM) dalam penjualan kerajinan tangan pada Toko Glass Fahraz dapat memberikan solusi terhadap permasalahan yang dihadapi karena dapat membantu dalam pemasaran penjualan kerang, menjaga hubungan dengan pelanggan, meningkatkan pelayanan terhadap pelanggan, serta memberikan kemudahan kepada pelanggan dalam melakukan transaksi pembelian. Implementasi sistem ini dibagi menjadi tiga bagian yaitu implementasi antarmuka konsumen, member dan admin.

Implementasi antarmuka konsumen terdiri dari beberapa menu antara lain beranda, tentang kami, cara pembelian, daftar, login, kategori produk. Implementasi antarmuka member terdiri dari menu yang sama dengan konsumen, ditambah dengan member bisa melakukan pembelian barang, konfirmasi pembayaran dan memberikan komentar terhadap produk. Berikut adalah tampilan implementasi antarmuka konsumen dan member.

\section{Tampilan Halaman beranda}

Halaman beranda merupakan halaman awal yang dijumpai setelah konsumen masuk ke dalam website Toko Glass Fahraz.

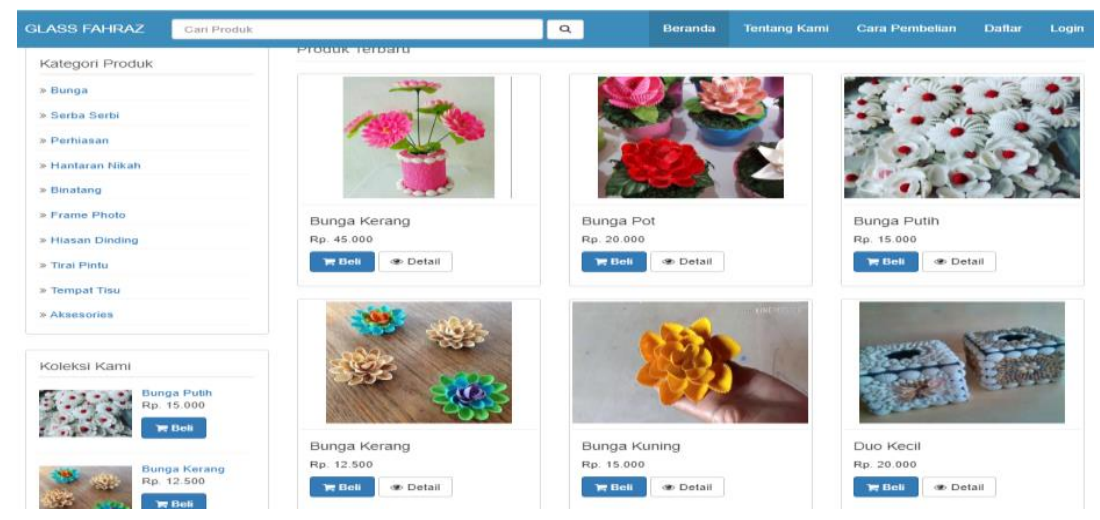

Gambar 1. Halaman Beranda

\section{Halaman Daftar}

Pada saat konsumen hendak melakukan pembelian produk maka konsumen harus melakukan pendaftaran akun terlebih dahulu. 
Vol. 1 No. 1, Feb 2021, hlm. $79-88$

DOI: https://doi.org/10.33330/.v1i1.1048

Available online at https://jurnal.stmikroyal.ac.id/index.php/jutsi

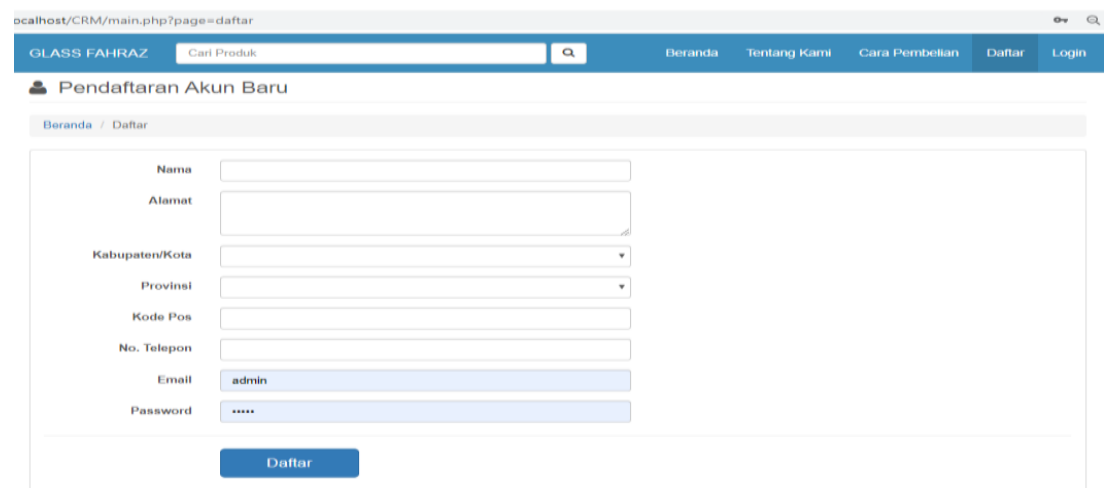

Gambar 2 Halaman Daftar Member

\section{Halaman Pembelian Produk Member}

Setelah login ke dalam sistem, maka akan ditampilkan halaman beranda member dimana member bisa melakukan pembelian produk.

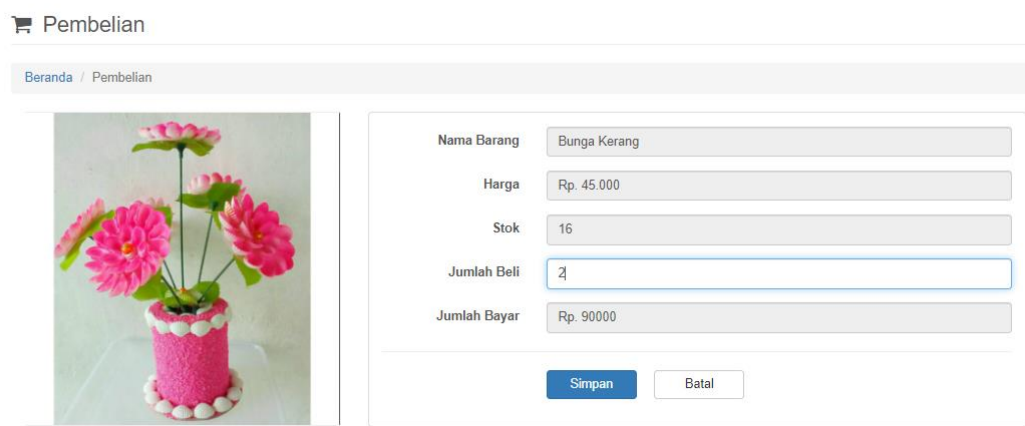

Gambar 3 Halaman Pembelian Produk Member

\section{Tampilan Halaman Keranjang Belanja Member}

Setelah selesai mengisi jumlah produk yang akan dibeli, selanjutnya tekan tombol simpan maka akan ditampilkan halaman keranjang belanja member. Jika member belum selesi belanja maka klik tombol lanjutkan belanja, jika member sudah selesai klik tombol selesai belanja.

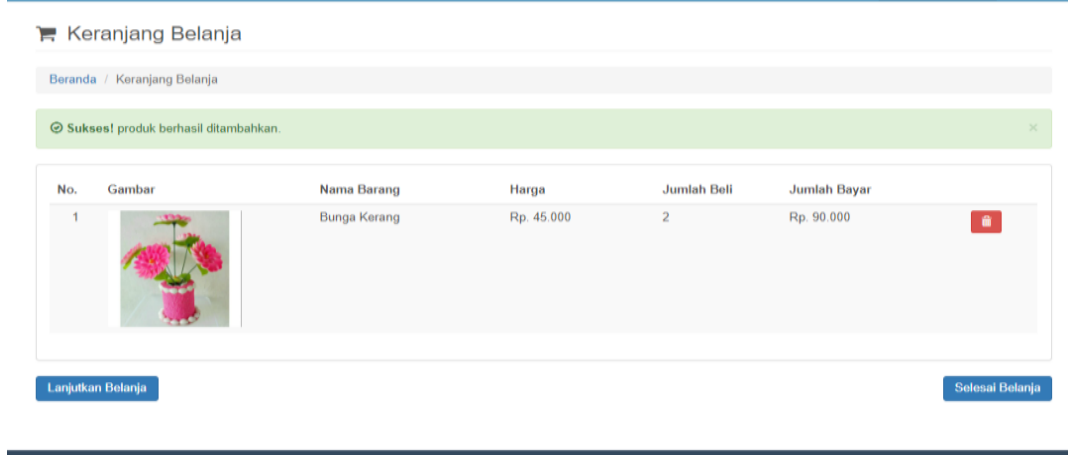

Gambar 4. Halaman Keranjang Belanja Member

\section{Tampilan Halaman Proses Order Member}

Selanjutnya sistem akan menampilkan halaman proses order yang telah dilakukan member. Klik tombol proses order untuk melakukan pemesanan produk. 
Vol. 1 No. 1, Feb 2021, hlm. $79-88$

DOI: https://doi.org/10.33330/.v1i1.1048

Available online at https://jurnal.stmikroyal.ac.id/index.php/jutsi

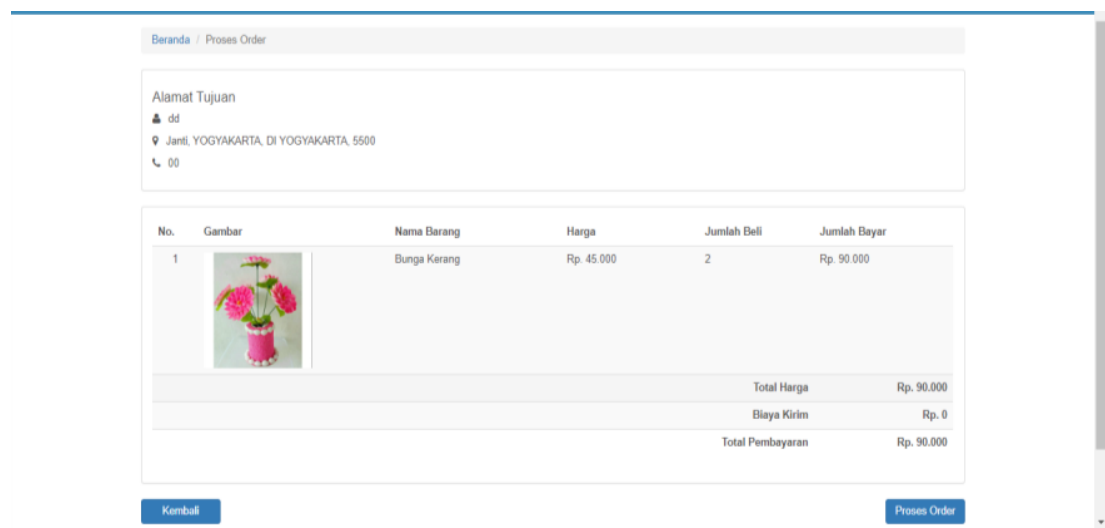

Gambar 5. Halaman Keranjang Belanja Member

\section{Tampilan Halaman Pembayaran}

Kemudian akan ditampilkan halaman untuk melakukan pembayaran dengan cara transfer melalui rekening yang sudah tertera dihalaman pembayaran.

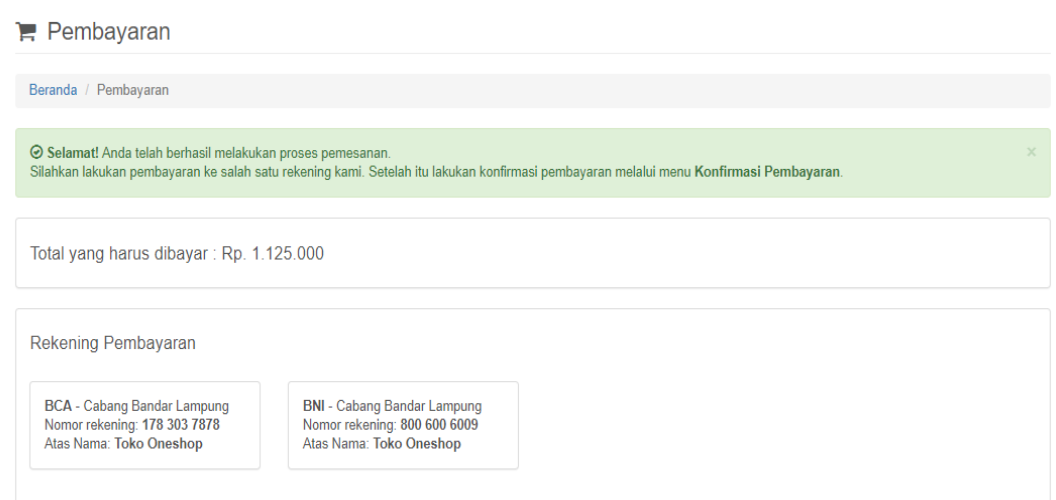

Gambar 6. Halaman Pembayaran

\section{Tampilan Halaman Konfirmasi Pembayaran}

Setelah member melakukan pembayaran selanjutnya klik sub menu pembelian dan pilih konfirmasi pembayaran.

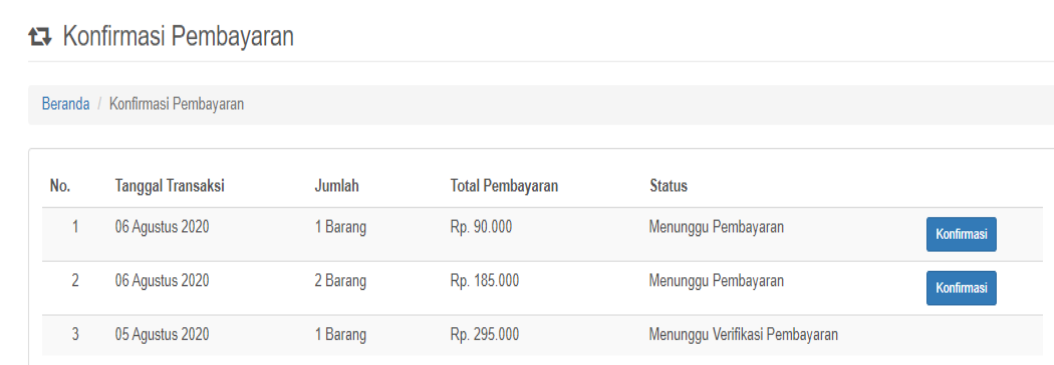

Gambar 7. Halaman Pilih Konfirmasi 
Vol. 1 No. 1, Feb 2021, hlm. $79-88$

DOI: https://doi.org/10.33330/.v1i1.1048

Available online at https://jurnal.stmikroyal.ac.id/index.php/jutsi

Setelah di klik tombol konfirmasi selanjutnya sistem akan menamilkan form untuk melakukan konfirmasi pembayaran.

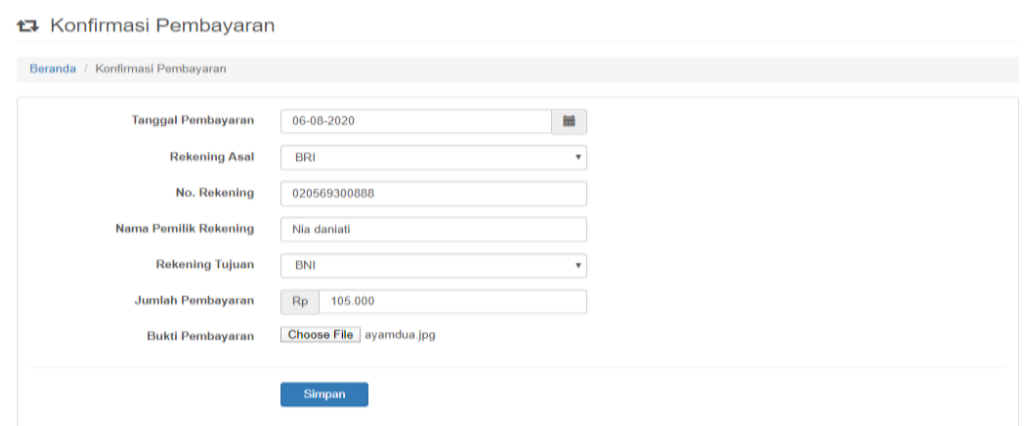

Gambar 8. Halaman Konfirmasi Pembayaran

\section{Tampilan halamans status Pembayaran diterima}

Selanjutnya ada pesan konfirmasi pembayaran berhasil ditampilkan. Member menunggu admin menerima status pembayaran. Setelah admin menerima status pembayaran maka status akan berubah dari menunggu menjadi pembayaran diterima.

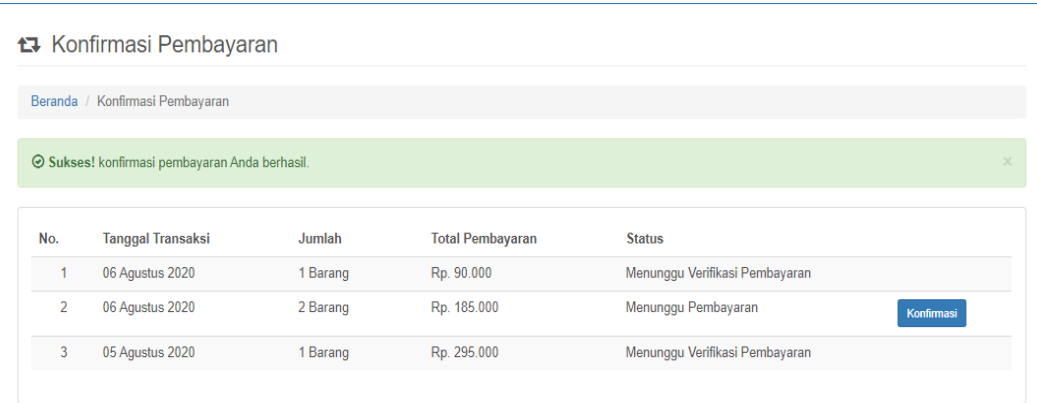

Gambar 9. Halaman Konfirmasi Pembayaran

\section{Tampilan halaman Komentar}

Member bisa memberikan komentar atau testimoni terhadap produk yang sudah di beli dan pelayanan dari Toko Mode Fashion terhadap member. Selanjutnya admin akan membalas komentar tersebut dan muncul dihalaman publik.

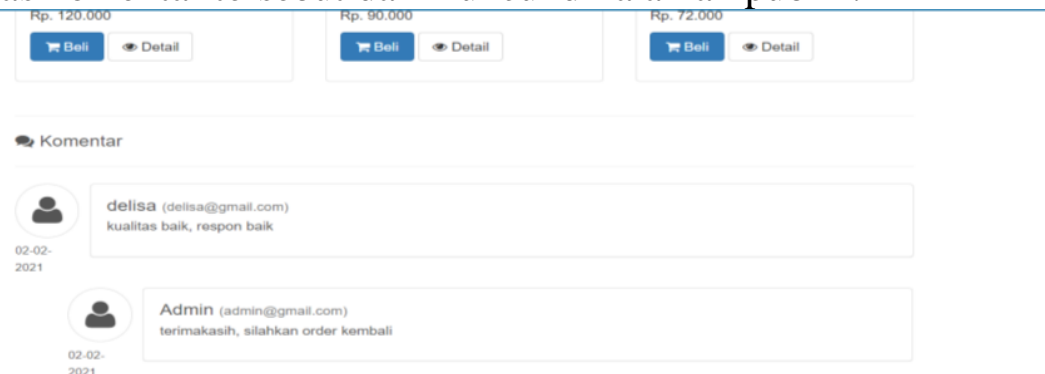

Gambar 10. Halaman Komentar

Implementasi antarmuka admin terdiri dari beranda, informasi, konsumen, barang, biaya pengiriman, transaksi, komentar, laporan, ubah password dan logout. 
Vol. 1 No. 1, Feb 2021, hlm. $79-88$

DOI: https://doi.org/10.33330/.v1i1.1048

Available online at https://jurnal.stmikroyal.ac.id/index.php/jutsi

Berikut adalah tampilan implementasi antar muka admin.

\section{Tampilan Halaman Beranda Admin}

Halaman beranda merupakan halaman awal setelah admin memasuki website Toko Glass Fahraz, tampilan halaman beranda admin dapat dilihat pada gambar berikut:

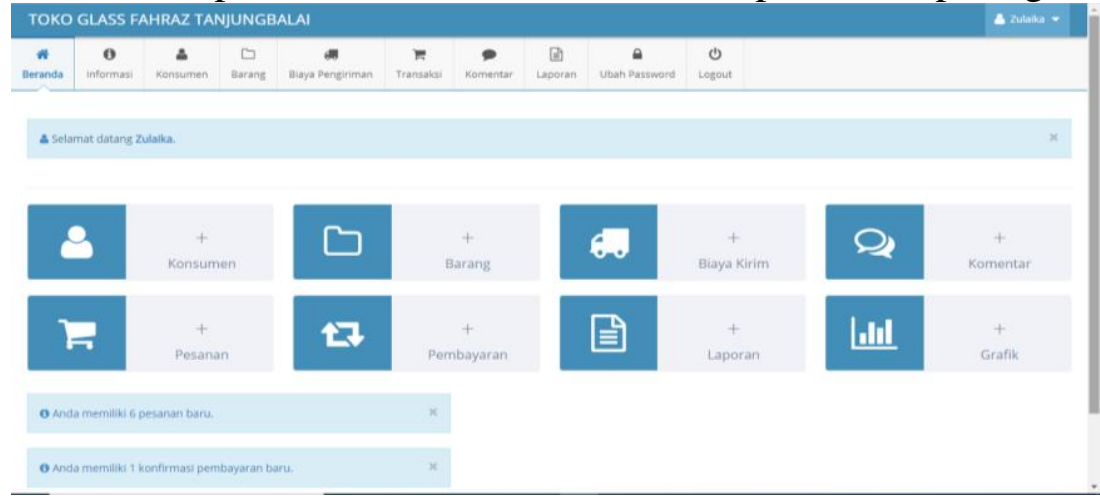

Gambar 11. Tampilan Halaman Beranda Admin

\section{Tampilan Halaman Informasi}

Pada menu informasi terdapat dua sub menu yaitu tentang kami dan cara pembelian. Tentang kami berisi profil Toko Glass Fahraz Tanjung balai, sedangkan menu cara pembelian merupakan halaman petunjuk cara melakukan pembelian produk. Pada halaman ini admin dapat melakukan pengelolaan data yaitu ubah data.

Tentang Toko Glass Fahraz Tanjungbala

Toko GLASS FAHRAZ berdiri sejak 14 april 2012 yang belokasi Toko di Pematang Pasir, Tanjungbalai. Pemilik Toko bernama ibu Syamsidar. Usaha kerajinan tangan yang dijual terbuat dari kerang dan siput yang dikombinasi dengan manik-manik dan lain-lain, terdiri dari bermacam-macam jenis antara lain tempat tisu, tirai, aksesories, hiasan dinding, bunga dan hantaran pernikahan. Usaha Kerajinan tangan ini banyak di gemari orang karena unik dan menarik.

Gambar 12. Tampilan Halaman Informasi

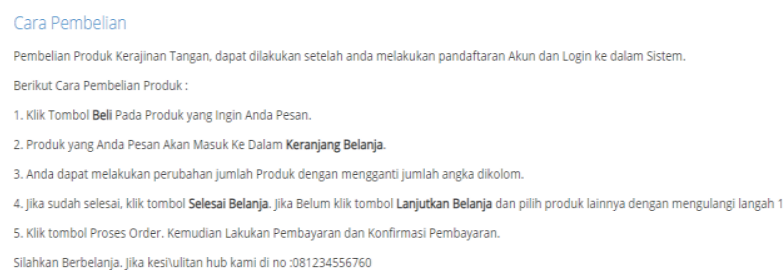

Gambar 13. Tampilan Halaman Cara Pembelian

\section{Tampilan Halaman Konsumen}

Pada menu konsumen terdapat data semua konsumen yang sudah melakukan pendaftaran sebagai member pada website Toko Glass Fahraz. Admin dapat melihat semua data member tersebut. 
Vol. 1 No. 1, Feb 2021, hlm. $79-88$

DOI: https://doi.org/10.33330/.v1i1.1048

Available online at https://jurnal.stmikroyal.ac.id/index.php/jutsi

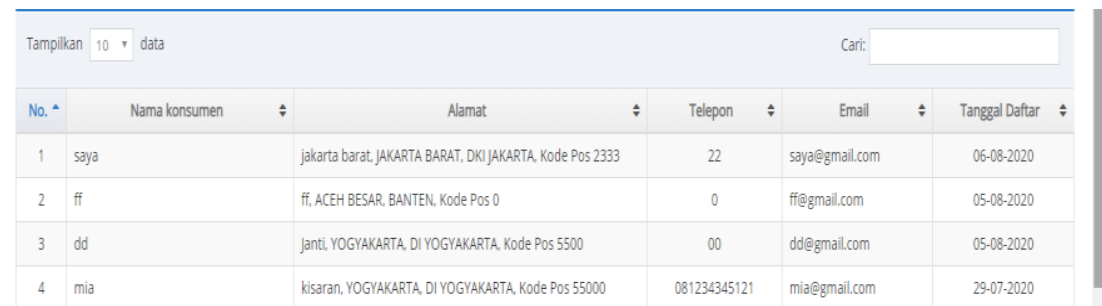

Gambar 14. Tampilan Halaman Cara Konsumen

\section{Tampilan Halaman Barang}

Pada menu barang terdapat dua sub menu yaitu produk dan kategori produk. Pada halaman ini admin dapat melakukan pengelolaan data produk yaitu tambah, ubah dan hapus produk maupun kategori produk sekaligus proses pencarian data.

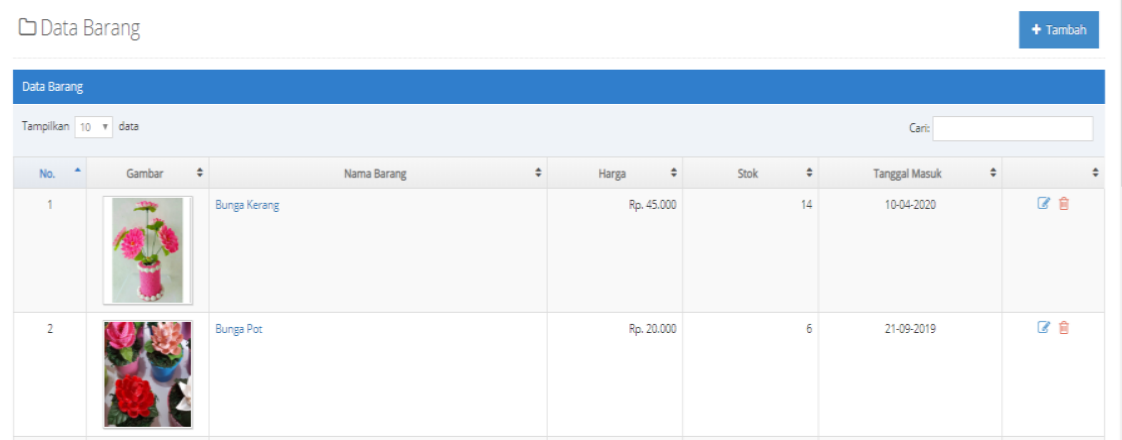

Gambar 15. Tampilan Halaman Barang

\section{Tampilan Halaman Biaya Pengiriman}

Pada menu biaya pengiriman, admin dapat melakukan pengelolaan data biaya pengiriman, seperti menambah, mengubah maupun menghapus data biaya pengiriman.

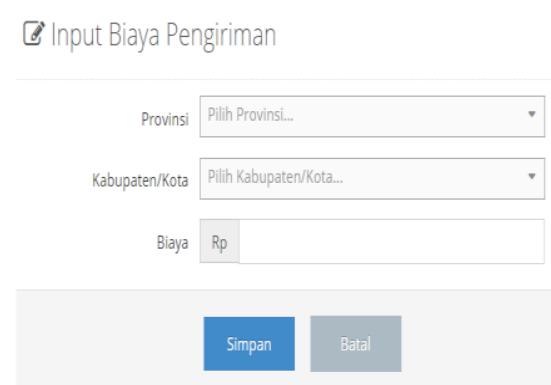

Gambar 16. Tampilan Halaman Biaya Pengiriman

\section{Tampilan Halaman Transaksi}

Pada menu transaksi, terdapat dua sub menu yaitu pesanan dan konfirmasi pembayaran. Admin dapat melihat data pesanan/order yang telah dilakukan member. 
Vol. 1 No. 1, Feb 2021, hlm. 79 - 88

DOI: https://doi.org/10.33330/.v1i1.1048

Available online at https://jurnal.stmikroyal.ac.id/index.php/jutsi

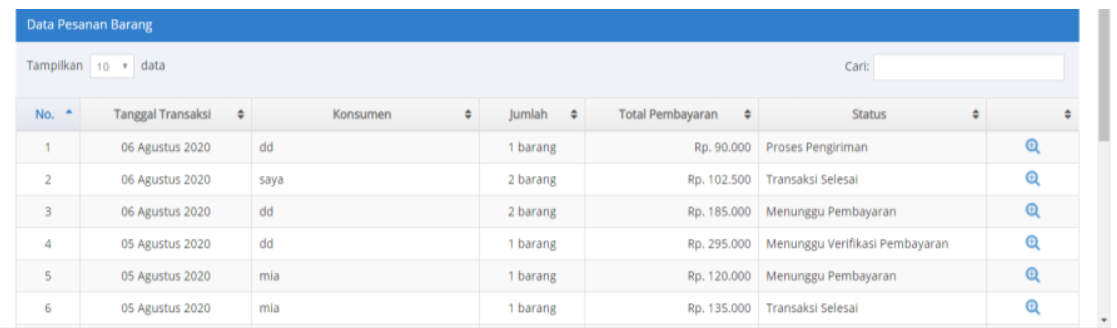

Gambar 17. Tampilan Halaman Transaksi

Selanjutnya dari halaman transaksi, admin memilih konfirmasi pembayaran. Admin memverifikasi status pembayaran dengan menekan tombol Terima.
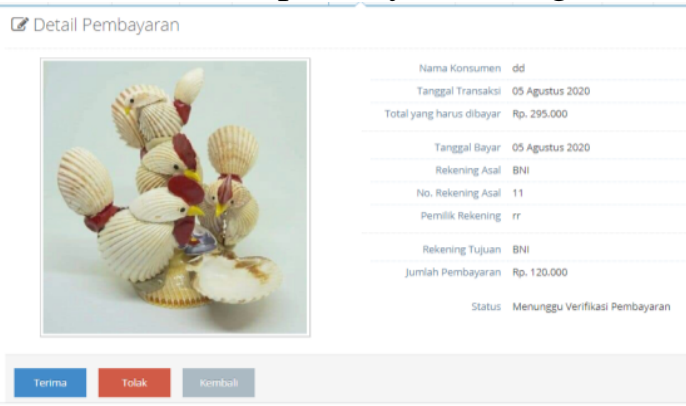

Gambar 18. Tampilan Halaman Konfirmasi Pembayaran

\section{Tampilan Halaman Komentar}

Pada halaman komentar, admin dapat melihat komentar yang diberikan oleh member dan membalas komentar tersebut.

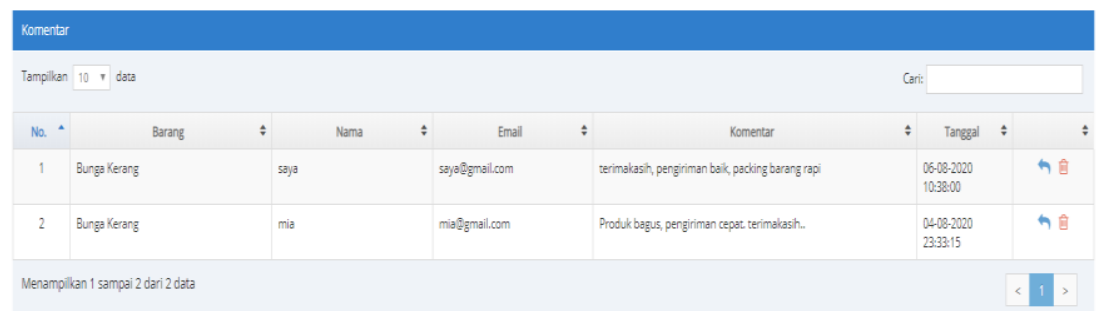

Gambar 19. Tampilan Halaman Halaman Komentar

\section{Tampilan Halaman Laporan}

Pada halaman laporan, terdapat dua sub menu yaitu laporan dan grafik. Berikut tampilan halaman laporan penjualan kerajinan tangan:

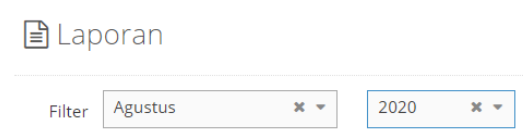

Gambar 20. Tampilan Halaman Laporan 
Vol. 1 No. 1, Feb 2021, hlm. $79-88$

DOI: https://doi.org/10.33330/.v1i1.1048

Available online at https://jurnal.stmikroyal.ac.id/index.php/jutsi

Admin dapat memilih grafik dan melihat grafik penjualan kerajinan tangan. Berikut tampilan grafik penjualan kerajinan tangan.

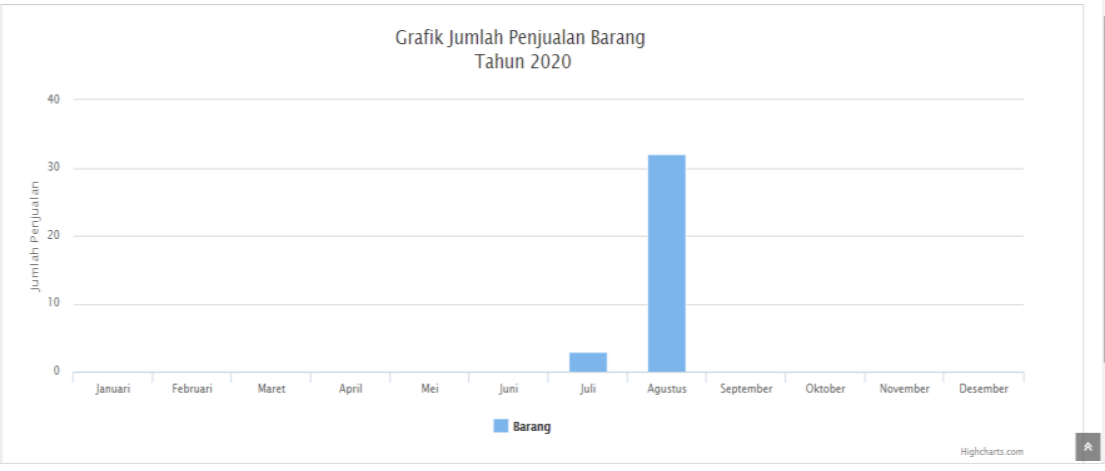

Gambar 21. Tampilan Halaman Grafik

\section{SIMPULAN}

Berdasarkan implementasi dan pengujian yang telah dilakukan, maka dapat diambil beberapa kesimpulan : (1) Penerapan metode Customer Relationship Management (CRM) dalam sistem informasi penjualan pada Toko Glass Fahraz dapat memberikan informasi produk terbaru, diskon dan penawaran lainnya serta memberikan fasilitas komentar bagi pelanggan., (2) Implementasi Customer Relationship Management (CRM) dalam sistem informasi penjualan kerajinan tangan pada Toko Glass Fahraz dapat memberikan kemudahan bagi pelanggan untuk melakukan transaksi pembelian produk secara online.

\section{DAFTAR PUSTAKA}

[1] Carissa, O. A., Fauzi, A., \& Kumadji, S. 2014. "Penerapan Customer Relationship Management (CRM) Sebagai Upaya Untuk Meningkatkan Loyalitas Pelanggan (Studi Kasus Pada Bandung Sport Distro Malang)", Jurnal Administrasi Bisnis, Vol.15, No.1, h.1-11 (Online).

[2] Fardhani, K. F., Rachmawati, I., \& Prabowo, F. S. 2016. Pengaruh Custorelationship Management (CRM) Terhadap Loyalitas Pelanggan English First Samarinda The Effect Of Customer Relationship Management ( CRM ) On Customer' S Loyalty Of English First Samarinda. E-Proceeding Of Management, 3(2), 986-989

[3] Malawat, S.M., Harwini, D., Mulyani, N., Hutahaean, J. 2018. "E-Commerce Penjualan Menggunakanmetode Customer Relationship Management(CRM)". Jurnal Mantik Penusa Vol. 2, No. 2 Desember 2018, pp. 98-104.

[4] Rosinta, E., Hasibuan, D. 2018. "Implementasi Customer Relationship Management (CRM) Pada Aplikasi Penjualan Berbasis Web PT. Buana Telekomindo". Jurnal TIMES Volume VII No 1, Juni 2018 hal. 8 - 14. 